\title{
Ross $v$ Chambers: Assimilation law and policy in the Northern Territory
}

\author{
Katharine Booth and Lisa Ford
}

On 9 September 1955, Jack Chambers, co-owner of Eva Downs Station in the Northern Territory, had an argument with his Aboriginal cook, Dolly Ross. That morning, Ross had refused to prepare breakfast for her fellow Aboriginal pastoral workers because she said she was ill. Chambers claimed that Dolly was malingering because she had quarrelled with her husband. After the argument, Dolly, her husband Jim and a minor named Munro left the station. Chambers claimed that he had ordered them off the property. The Ross family testified that they had left in protest when Chambers threatened to 'liven up' Dolly if she did not do her work. Later that morning, Jack Chambers, Colin Chambers, manager Jack Britt, and stockmen George Booth and Francis Booth rode out from the station either to muster cattle or to pursue the Ross family. Either motive was possible: there were cattle to be mustered and all hands were needed on deck.

The two parties met on the road a kilometre from Eva Downs. Their stories about what happened next differ fundamentally. The Chambers brothers claimed that Dolly and her family blocked the road and aggressively brandished sticks and boomerangs. Dolly, Jim and Munro said that the Chambers party attempted to run them down and that they held up their swags to deflect the horses. Whatever occurred, their confrontation ended in Jim Ross's beating and the repeated horsewhipping of all three. They were then driven back towards the station. Just inside the homestead gate, the party was confronted by two Aboriginal stockmen, Isaac Isaacs and Dinny McDinny, who, by all accounts, had come to defend the Ross family against the violence of their employers. The Chambers brothers attested at trial, Isaac attempted to 'belt' Jack Chambers with an iron bar. George Booth then fired two revolver shots over their heads, 
he claimed, to stop the 'murderous attack'. ${ }^{1}$ The rescuers' efforts failed. Isaacs and McDinny were overpowered by the Chambers brothers and, McDinny's wife, Eileen, recalled much later, Chambers 'flogged them too, he rode them down and chased them back to the stockyard and he flogged them all again'. ${ }^{2}$ Colin Chambers then beat Isaacs with his fists at the Eva Downs aerodrome.

The Ross family, Isaacs and McDinny went back to work, despite their injuries. Either that night, or eight days later, the whole party escaped together with their families in the evening, travelling at night to avoid detection. ${ }^{3}$ The Chambers brothers did not let them go without protest. They telegraphed Constable Corbin alleging that a group of Aboriginal employees were heading towards Anthony's Lagoon with a stolen axe and water bag. Corbin sent out a search party and, two days later, an Aboriginal tracker called Dick brought McDinny and Isaacs to the local police station. They had been sent ahead to get help because Jim Ross had been crippled by his wounds. Corbin drove out on 19 September to find the rest of the party. They were hiding at Turkey's Creek, 50 kilometres away, with neither the Chambers brothers' axe nor the water bag in their possession. Constable Corbin reported that Dolly Ross bore 21 lash marks, Jim Ross, 47 and Munro, 6. Ten days after the assaults at Eva Downs Station, Dolly and Jim's wounds were suppurating. ${ }^{4}$ The Chief Welfare Officer at Borroloola, Ted Evans, noted that many of Dolly's wounds were still open a week later. ${ }^{5}$ For their part, McDinny bore the marks of 4 lashes, whereas Isaac had 19 lash wounds on his body. McDinny carried the scars of this flogging 50 years after the assaults took place. ${ }^{6}$

The incident at Eva Downs is one of the best documented occurrences of violence against Aboriginal pastoral workers in the mid-century Northern Territory. The incident made national and international news. ${ }^{7}$ But this incident is much more than another story about racist brutality. It ended in the sensational conviction of the Chambers brothers for violence against their

\footnotetext{
Sydney Morning Herald, 15 December 1955; The Age, 15 December 1955.

McDinny 1987.

Corbin to Officer in Charge, Southern Division, Alice Springs, NT, 23 September 1955, 10-12; contrast, Evans to Officer in Charge, Southern Division, Alice Springs, 23 September 1955, 9. Both in Northern Territory Welfare Branch - Eva Downs Station 1955-1958, NAA F1, 1955/1154 [henceforth NTWB 1955/1154].

Corbin to Officer in Charge, Southern Division, 23 September 1955, NTWB 1955/1154, 10-12.

Evans to Giese, 26 September 1955, NTWB 1955/1154, 8.

Roberts 2009.

'Natives flogged with stockwhips, counsel alleges', Canberra Times, 13 December 1955: 2; 'Whites beat five natives with stockwhips', The Argus, 13 December 1955: 7; 'Natives waited in ambush - cattle man tells court', The Argus, 14 December 1955: 1; “'No, no - please stop"', The Argus, 14 December 1955: 5; 'White men ambushed, accused tells court in whip flogging case', Canberra Times, 13 December 1955: 2; 'Natives had white men in dire danger', The Argus, 15 December 1955: 5; 'Cattleman weeps after "stockwhip" sentence. 2 Gaoled, fined $£ 800$ for flogging', The Argus, 16 December 1955: 1; 'Graziers gaoled and fined for whipping natives', Canberra Times, 16 December 1955, 1; 'Whipping of five Aborigines: Prison for brothers', Manchester Guardian, 16 December 1955: 9; Douglas 2004: 301, 304. See Douglas 2004: 301.
} 
Aboriginal workers. ${ }^{8}$ Colin and Jack Chambers and the three stockmen were charged in the Tennant Creek Police Court on 17 October 1955, with 10 counts of assault occasioning actual bodily harm to the victims. ${ }^{9}$ The group (excluding Francis Booth, a minor) was then tried before Justice Kriewaldt without a jury from 12 to 15 December $1955 .{ }^{10}$ Justice Kriewaldt found Britt to be 'reluctant and unwilling ... perhaps little more than a spectator' and acquitted him of all 10 charges. George Booth was fined $£ 25$ for several counts of aiding and abetting their employers' assaults and his licence to employ Aboriginal people was revoked. However, Kriewaldt found Colin and Jack Chambers guilty on most counts, fined each a sum of $£ 400$, and jailed both for six months with hard labour. ${ }^{11} \mathrm{He}$ had never before convicted let alone jailed a white person for assaulting an Aborigine. ${ }^{12}$

This article focuses on another, much less studied case stemming from the Eva Downs incident. In the months after the conviction, the Northern Territory Administration, under intense pressure from humanitarian groups and the federal government, brought a civil suit on behalf of Ross et al. against Colin and Jack Chambers. This litigation produced a little-known watershed decision by Justice Kriewaldt. He denied that the Crown could sue on behalf of the victims, reading down legislation defining Aboriginal people as wards of the state and strongly endorsing the legal standing of adult Aboriginal people before Australian courts. ${ }^{13}$ This repudiation of state paternalism deeply troubled the administration. As a result, the Welfare Ordinance 1953 (NT) was amended to bolster the power of the state over Aboriginal wards. ${ }^{14}$ In this paper, we explore new archival materials that minutely document this litigation, and through it, the practical and ideological dilemmas confronting Aboriginal welfare administration in the Northern Territory at this watershed moment. The civil case collapsed in the aftermath of Kriewaldt's decision. We show that it did so because of a combination of internal contradictions in the logic and practice of 1950s assimilation policy and practical difficulties arising from the distance and difference separating welfare officers from Aboriginal workers.

\footnotetext{
$8 \quad R \quad v$ Sydney John Chambers, Colin James Chambers, Jack Britt and George David Booth (Unreported Judgment) [1955] NTSC No 55 of 1955, 291; Douglas 2005, 55-7.

9 See letter from J.C. Archer to The Secretary, Department of Territories, 29 December 1955, NTWB 1955/1154, unnumbered (59)-61.

10 Transcript of $R v$ Chambers, NTWB 1955/1154, 35-59, 39.

11 The Age, 16 December 1955; Archer to Secretary, Department of Territories, 29 December 1955, NTWB $1955 / 1154,[59]-61$. The sum of $£ 400$ was a considerable financial burden (roughly equal to AU\$10,500 today).

12 Douglas 2005: 59.

13 Transcript of Judgment, Ross $v$ Chambers, April 1956, NTWB 1955/1154, 86-102.

14 Correspondence makes clear that the 1957 amendments were drafted in response to Kriewaldt's judgment: Lambert to Archer, 13 June 1956, NTWB 1955/1154, 124. They took the form of s.4 of the Welfare Ordinance 1957, No. 42, 1957 (Marginal note, Welfare Ordinance, 1953-1960, www.austlii.edu.au).
} 
The intellectual history of assimilation has been richly retold of late - Russell McGregor and Tim Rowse in particular have delivered nuanced expositions of deep commitment and deeper intellectual disagreements within the ranks of assimilationists about the value of preserving Aboriginal culture, and of the rich interface of government administrators with evolving humanitarian critiques. Rowse has recently pushed his analysis further - demonstrating the power of postwar bureaucratic thinking about population management and statistics to challenge countervailing discourses about Aboriginal culture and Indigenous rights.

This work engages deeply with the intellectual contributions of key policymakers - A.P. Elkin and Paul Hasluck. It is richly supplemented by the work of Alison Holland on Mary Bennett and Rani Kerin's on Charles Duguid, tracking their critiques and intersections with government policy. Our work builds most closely on a slightly different strand of this new historiography. It resembles John Murphy's very recent exploration of the pragmatic and principled discussions of government bureaucrats that underpinned the extension of welfare benefits to Aboriginal people after World War Two. ${ }^{15}$ In this article, we use newly discovered interdepartmental correspondence to tell a hidden, bureaucratic and legal history of Aboriginal subjecthood in practice. The Ross litigation exposed deep fissures between the administration and the judiciary, and within the administration, about the nature of state power over Aboriginal people in the Northern Territory and the meaning of Aboriginal legal subjecthood, of assimilation and of the proper boundaries of protection in the aftermath of the United Nations Universal Declaration of Human Rights. A more nuanced understanding of 1950s policy lies somewhere in this minutely documented mess of principles and practice.

\section{Assimilation and the Hasluck Administration}

The Eva Downs incident occurred at a time of deep change in Aboriginal policy in the Northern Territory. Since the much-discussed national conference in 1937, Australian Aboriginal policy had shifted towards the notion that Aborigines were latent citizens and that Aboriginal citizenship was compromised by Aboriginal culture rather than Aboriginal race. This notion was only partly digested into legislation. After 1937, states around Australia had crafted policies aimed at incorporating 'half-caste' or mixed race Indigenous people into Australian

15 Holland 2015; Kerin 2011; McGregor 2011; Murphy 2013; Rowse 1998, 2012. For a formative overview of humanitarianism in Australian history that exemplifies the new scholarly impulse to take humanitarians seriously, see O'Brien 2015. 
society. ${ }^{16}$ Though the Commonwealth Government lacked constitutional power to legislate Indigenous policy for the states until 1967, the Northern Territory Administration strove to lead the way by example. In 1939, J. McEwen declared a New Deal for Aborigines - promising a new administration, headed by a director and supported by anthropologically trained district and patrol officers distributed throughout the Territory, to protect Aboriginal labourers and educate and police Aboriginal people. 'Half-caste' children born out of wedlock would be taken into state custody and educated, chiefly, in useful trades. They and detribalised Aborigines would be educated into citizenship. Uncivilised and semi-tribalised Indigenous people required intergenerational assistance. They would be brought within the reach of government by patrols and trained, judged, imprisoned and/or cared for according to their needs on outback stations. ${ }^{17}$ McEwen's plans were interrupted by the war. After the war, they were adapted and implemented by Hasluck - whose own thinking about assimilation was both transformative and eccentric. ${ }^{18}$ As Elkin argued, Hasluck advocated 'a type of assimilation ... [predicated on] the complete change of Aborigines in all but skin colour'. This was a vision that Elkin thought 'impossible' and 'demeaning' to Indigenous peoples and their cultures. ${ }^{19}$ Hasluck's core contention was that the 'aboriginal problem ... was a social problem and not a racial one'. McGregor and Rowse describe this as a species of 'liberal individualism' ${ }^{20}$ Membership of a political community, for Hasluck, was not 'contingent on religion, class or race'. It was contingent on affective membership: 'Not only must the majority absorb minorities, but the individuals from those minorities must relinquish their loyalties to any sub-groups of the nation. ${ }^{21}$ Government policies coercive of Aboriginal people, in this light, were:

temporary measures, not based on race, but intended to meet their need for special care and assistance to protect them from any ill effects of sudden change and to assist them to make the transition from one stage to another in such a way as will be favourable to their social, economic and political advancement. ${ }^{22}$

One of its enduring manifestations was the 1953 Welfare Ordinance which came into effect only as the Ross litigation was drawing to a close. This document has been described both as a 'paradigm shift in the administration of Indigenous people's lives in the Northern Territory' and as 'window dressing' in which

16 For two of the most detailed analyses of state law in this period, see Haebich 2000; Galligan and Chesterman 1997.

17 McEwen 1939. See Rowley 1970: 328-32.

18 On his eccentricity, see McGregor 2005, 2011: 77.

19 Elkin as paraphrased by McGregor 1999: 244.

20 Though note that they disagree about the degree of individualism: McGregor 2011: 78 and 202, n9.

21 Rowse 1998: 109.

22 Rowse 1998: 110. 
'most of the old injustices are continuing unchanged'. ${ }^{23}$ The 1953 Welfare Ordinance embodied Hasluck's vision by couching Aboriginal welfare administration in the Northern Territory in the language of living standards instead of race. Using race-neutral language to implement racist policy is not a new trick in a country whose White Australia immigration policy was defended by a dictation test. But the Ordinance - at least in its drafting - was more sincere. The Ordinance used the word 'Aboriginal' in exactly two sections, one schedule repealing former Aboriginal Ordinances and another referring to state legislation on the subject. Its central provision gave the 'Administration' power to 'declare a person to be a ward' if their 'manner of living'; 'inability ... to manage his own affairs'; 'standard of social habit and behaviour' and 'personal associations' suggested that he needed 'special care and assistance' under the Ordinance. ${ }^{24}$ Its implementation was less nuanced. Despite its careful wording, the Ordinance established a race-based system of administration. It extended wardship automatically to Aborigines subject to state Aboriginal protection legislation. Officers of the Welfare Administration automatically included anyone considered to be a 'full blooded' Aborigine (including all of the Eva Downs victims) in the list of Territorians drawn within its ambit. ${ }^{25}$

By the time of the Eva Downs incident, the protection of Aboriginal labour was more than a bureaucratic concern. As Bain Attwood, Holland and Kerin have shown, interest in Aboriginal 'enslavement' and subordination had flowered in the 1930s. ${ }^{26}$ Writers like Mary Bennett forged new links with the British AntiSlavery Society and mounted powerful critiques of state and federal policy in the sphere of Indigenous affairs. ${ }^{27}$ These critiques intensified and proliferated in the context of the explosion of human rights talk in the aftermath of World War Two. The Holocaust, the Declaration of Human Rights, and the fact that Indigenous men worked for the Australian army combined to add new force to pre-war calls for Indigenous rights. By the 1950s, Hasluck operated in fear of the electoral ramifications of humanitarian critique, as we will see. Indeed, Hasluck's dismissal of Aboriginal culture had come under strenuous academic attack by the time he left office. ${ }^{28}$

\footnotetext{
23 Chesterman and Douglas 2009: 24; compare CAR Bulletin, no. 8, April 1956, quoted in Attwood 2003: 139. McGregor, in particular, emphasises its continuities with the 1939 'New Deal' and the Aboriginals Ordinance of 1918 - McGregor 2011: 82.

24 Welfare Ordinance 1953 (NT), s. 14; Chesterman and Douglas 2009.

25 Chesterman and Douglas 2009: 73-74.

26 Attwood 2003. In the context of welfare rights, see Murphy 2013: 213-17.

27 E.g. Holland 2001, 2015.

28 Rowse 2012: 39-44.
} 
Meanwhile, Aboriginal men and women in the Territory were increasingly active in defence of their civil rights. By the end of the war, 662 Aboriginal men and 73 Aboriginal women were employed by the army. ${ }^{29}$ Aborigines enjoyed a much higher standard of living working for the army than they did on cattle stations. The army guaranteed £5 per week to labourers at a time when many workers were not paid cash wages at all on cattle stations. ${ }^{30}$ Rations, clothing, accommodation and medical services were provided to dependants, as well as basic schooling for Aboriginal children. ${ }^{31}$ According to Catherine and Ronald Berndt, prominent anthropologists who gathered first-hand data from various Northern Territory cattle stations from 1944 to 1946, employment in the army set a precedent below which it was unwise for pastoralists to fall. ${ }^{32}$

Most important, according to scholars and Indigenous informants, was Aboriginal experience of relative equality and respect in the army. Ann McGrath suggests that the army gave Aboriginal people 'that sense of being on the same standing, the same level as the whites. They saw that as equity, having tasted that' ${ }^{33}$ Alec Kruger, an Aboriginal soldier who fought in the war, stated that he had 'seen a bit of the world where I was treated with a bit of respect, and I wanted to recapture it' $^{3}{ }^{34}$ When both the Commonwealth and station owners demanded Aboriginal people return to their subservient, pre-war role, they could not erase the new expectations of Aboriginal labourers. Many were angered by 'the attitude of a staid group who wanted to subjugate, control and basically render people subservient again' ${ }^{35}$

Working with communists, unionists and humanitarians, Aboriginal workers turned to activism in the postwar North. ${ }^{36}$ So much is clear from the increase in Aboriginal workers 'walking-off' cattle stations. One of the more famous examples is the 1946-49 strike on several Pilbara cattle stations for higher wages. ${ }^{37}$ Similarly, on Wave Hill Station in 1947, a patrol officer reported that four Aboriginal employees had left the station and had said 'they were just like white men and could leave the job when they felt like it' ${ }^{38}$ In September 1955 ,

\footnotetext{
29 Bunbury 2002; Powell 1982; Riseman 2012.

30 Hall 1989: 135. It was only in 1947 that Regulation 14 of the Aboriginals Ordinance 1918 (Cth) was repealed. This regulation had allowed pastoralists to avoid paying wages where they were able to prove that they were maintaining the employee's relatives and dependants: see Aboriginals Ordinance.

31 Powell 1982: 215-16; Saunders 1995: 114.

32 Catherine and Ronald Berndt quoted in Powell 1982: 217. Berndt and Berndt 1987.

33 Bunbury 2002: 44; Powell 1982: 216.

34 Kruger 2007: 146-48.

35 Bunbury 2002: 44.

36 See May 1994.

37 Broome 2010: 143.

38 Hokari 2011.
} 
the same month as the Chambers assaults, Aboriginal staff at Wave Hill went on strike. ${ }^{39}$ The following year, the Wave Hill Police Journal alleges that some Aboriginal stockmen again refused to work at Wave Hill Station. ${ }^{40}$

\section{Assimilation in practice}

It is in this changing political and policy environment that the Eva Downs incident unfolded - and it exemplifies the awkward interface of the welfare and labour systems in a rapidly changing world. The incident was the result of Indigenous activism. According to Dawn May, Aboriginal pastoral workers could react to maltreatment in one of two ways - leaving the station or retaliating through physical force. ${ }^{41}$ The Ross family, Dinny and Isaac used both strategies. The Ross family walked out in protest against verbal abuse and the threat of violence. Dinny and Isaac rode out to physically defend them. Eileen McDinny suggests that Isaac and her husband, Dinny, shared bonds of kinship with the Ross family, and that the 'Law' required Dinny and Isaac to 'try and save their uncle'. ${ }^{42}$ All involved in the incident asserted rights as workers or band members that clearly surprised and unsettled the Chambers brothers.

At another level, the Eva Downs incident exemplifies the successful functioning of the postwar Welfare infrastructure. Scholars have noted the significant post1937 innovation of appointing local Welfare patrol officers to oversee and supplement policing of Aboriginal workers and of their pastoral employers in the Territory. ${ }^{43}$ But the Eva Downs incident shows much more than mere oversight. It shows local Welfare officials working closely with local policemen to defend the interests of Aboriginal workers. The Chambers brothers justified their violence first by making the explicit and powerful argument that they defended themselves against Aboriginal aggression and second by alleging that their Aboriginal workers were thieves. Police complicity in pastoral violence had a long history on Australian frontiers. ${ }^{44}$ Instead of collaborating in white violence, however, the local policeman, R.F.H. Corbin, worked closely with the local Welfare Officer, Ted Evans, to corroborate the complaints of the Indigenous victims. Corbin independently suggested to the chief officer at Alice Springs police station that indictments would have to be heard at 'Alice Springs where a more competent Bench will be available'. ${ }^{45}$ Indeed, his involvement in the

39 Sing 1992: 95.

40 Hokari 2011.

41 May 1983: 71.

42 McDinny 1987.

43 Douglas and Finnane 2012: 129-30.

44 Ford 2010: 97-107; Nettelbeck 2012; Nettelbeck and Foster 2007.

45 Corbin to Officer in Charge, Southern Division, Alice Springs, NT, 23 September 1955, NTWB 1955/1154, $10-12$. 
case was so consistent that, at their criminal trial, defence counsel argued that he had collaborated with the Aboriginal victims to firm up their story and to exaggerate their wounds. ${ }^{46}$

The Northern Territory Administration also responded with alacrity to reports of violence. Timing mattered here. The Territory's recently appointed Director of Welfare, H.C. (Harry) Giese, was a committed advocate of new assimilation policy. Within two days of finding the party, he had contacted the Superintendent of Police to ensure that the case progressed smoothly. ${ }^{47}$ The alleged perpetrators, Sydney John Chambers (Jack), Colin James Chambers, Jack Britt and George David Booth were indicted on 17 October, and the acting Northern Territory Administrator had informed the minister of the case by 19 October. Legal officers in Darwin and Canberra wrote briefs and analysed law to facilitate litigation. All levels of administration were involved in plans to ensure that the case came before Kriewaldt and was tried by a Queen's Counsel. Hansard reporters were sent to transcribe, verbatim, the evidence of the plaintiffs (though, unfortunately, the transcript seems to have been misfiled or lost). ${ }^{48}$ In short, every level of governance in the Territory and in Canberra joined the cause.

They did so in part to ward off mounting humanitarian critique. The Northern Territory became the particular focus of advocacy groups interested both in augmenting Commonwealth authority over Aboriginal affairs and in advocating for Aboriginal equality. Hasluck had been appointed Minister for the Territory in the fallout of the sensational arrest and 'banishment' of Fred Waters for leading Aboriginal workers in a strike in Darwin in 1951. ${ }^{49}$ The Eva Downs incident caused a similar media furore. Shirley Andrews, secretary of the Melbourne-based Council of Aboriginal Rights, led the charge to bring the Eva Downs case to the attention of the public and to pressure the Northern Territory Administration into action. The Council of Aboriginal Rights saw the case as a 'wonderful opportunity' to bring the plight of Territory Aborigines to the attention of the public. To this end, they collaborated with the Melbourne Herald to make the case front page news. The paper published exchanges between Andrews and Hasluck. When the criminal case ended in conviction, Andrews trumpeted 'the beginning of a new era for the station Aborigines' that would 'give to others the courage to stand up against ill treatment'. ${ }^{50} \mathrm{All}$ the while, she sent inquiries and suggestions to the offices of Hasluck.

\footnotetext{
$46 \quad R \quad$ Sydney John Chambers, Colin James Chambers, Jack Britt and George David Booth (Unreported Judgment) [1955] NTSC No 55 of 1955, 299.

47 Telegrams, 26-28 September 1955, NTWB 1955/1154, 2-5.

48 Archer to Lambert, 12 January 1956, NTWB 1955/1154, 65.

49 Attwood 2003: 131-36.

50 Attwood 2003: 142-43.
} 
Correspondence within the Northern Territory Administration makes clear that its actions in both the criminal and civil cases were calculated to minimise humanitarian accusations that they were 'not treating the case with the seriousness it deserves'. At the insistence of the Crown Law Officer, the ministry retained senior counsel 'at all costs' - a path cast as 'good tactics on the part of the Commonwealth' ${ }^{51}$ 'The point at issue', he noted, 'is that this case is likely to receive a great deal of publicity, irrespective of what the outcome is, and that publicity is bound to find its way overseas'.$^{52}$

The Acting Administrator, J.C. Archer, asked for guidance from Canberra about how best to manage correspondence from the Association for the Protection of Native Races and the Council of Aboriginal Rights about the case-correspondence that included enquiries about whether the administration was providing assistance to the 'Aborigines when they are giving their evidence',53 pressure to bring a civil action against the Chambers brothers and Booth; criticism of the light criminal sentence handed down by Kriewaldt; and claims that the incident provided more evidence of the 'enormous gap between regulations as they exist on paper and the carrying out of them by the station owners' of the Northern Territory. ${ }^{54}$ Ted Evans recalled in a memorandum to Giese that they had brought the civil action in part because of 'press reports wherein demands were made by certain Aboriginal Rights Societies that damages should be sought on behalf of the natives'..$^{55}$

Hasluck later reflected on what he felt was the unfair response of humanitarian interlocutors to the incident. In Shades of Darkness, an account of Aboriginal affairs between 1925 and 1965, Hasluck complained of the 'gross distortion' of the situation of Aboriginal people employed on cattle stations by several organisations who were 'active in spreading stories overseas to the discredit of Australia' to the London office of the Aborigines Protection Society, within United Nations circles and in several African countries. ${ }^{56}$ He referred specifically to an incident (likely the one at Eva Downs) where an Aboriginal worker was struck with a stockwhip by a white cattleman. Though the cattleman was subsequently arrested, tried and sentenced, Hasluck lamented that:

\footnotetext{
51 Lambert to Hasluck, 26 October 1955, NTWB 1955/1154, 14.

52 Lambert to Hasluck, 26 October 1955, NTWB 1955/1154, 14.

53 Swan to Hasluck, 28 October 1955, 15; Swann to Hasluck, 31 October 1955, 20; Unsigned (Canberra) to Admin Darwin undated, received 18 July 1956, 134; Lambert to Administrator of the Northern Territory, 29 May 1957, 186; Andrews to Hasluck, 24 February 1956, 81-82. All in NTWB 1955/1154.

54 For requests for guidance see, Archer to Lambert, 16 November 1955, NTWB 1955/1154, 198; and annotation on Archer to Lambert, 18 November 1955, NTWB 1955/1154, 19.

55 Evans to Giese, 13 January 1956, NTWB 1955/1154, 71-72.

56 Hasluck 1988: 98.
} 
This was not told as a story that it was against the law to strike an Aboriginal and that a strong penalty had been imposed on a white man for breaking the law. It was passed around as a story that black 'slaves' on Australian cattle stations were flogged when they displeased their slave-driving masters. ${ }^{57}$

Hasluck's protestations notwithstanding, that story of violence had deep roots in fact; as Ann McGrath showed previously, violence, the threat of violence, and Aboriginal memories of violence had played a key role in the organisation of Aboriginal labour on cattle stations from the outset..$^{58}$

In sum, the Eva Downs incident shows how genuine welfare reform combined with increasing public pressure pushed the Northern Territory Administration into frenetic action. The case provided an opportunity to model, not only for critics, but for the states, how Aboriginal welfare agencies might respond to protect as well as to infringe the civil rights of Aboriginal Australians. This goal was ultimately frustrated. Not only did the conviction of the Chambers brothers and Booth end in criticism and praise from the public, the civil case ended in ambivalence. Ross $v$ Chambers forced the Welfare and Northern Territory administrations into the invidious position of pitting their desire to do justice and punish abusive pastoralists against Aboriginal legal subjecthood and the wishes of the Aboriginal victims.

\section{The meaning of guardianship in a changing world}

The case of Ross $v$ Chambers made history without ever being fully resolved by a court. On 2 March 1956, the Crown Solicitor issued a writ against the Chambers brothers for more than $£ 2,000$ in damages (a sum claimed, according to the Associate Crown Law Officer, R.L. Odlum, on the very uncertain basis that Kriewaldt would treat the victims as 'white persons'). ${ }^{59} \mathrm{He}$ did so as 'next friend' of the Aboriginal victims and without their knowledge or consent. On 19 March, the Chambers brothers' solicitors applied:

to set aside the issue and service of the writ on the grounds that (a) no authority of the next friend had been filed at or before the issue of the writ; and (b) that the person named as next friend has and can have no authority to act as such under the Aboriginals Ordinance 1918-1953. ${ }^{60}$

57 Hasluck 1988: 98.

58 McGrath 1987: 106-15.

59 Odlum to Archer, 16 January 1956, NTWB 1955/1154, 74.

60 Transcript of Judgment, Ross v Chambers, April 1956, NTWB 1955/1154, 102. 
Kriewaldt upheld both of these contentions. In a remarkable endorsement of Aboriginal legal subjecthood, Kriewaldt declared that, 'Prima facie, an aboriginal of full age living in this Territory is subject to the same laws and entitled to the same rights and privileges as any other person living in the Territory'. While the provisions of the Aboriginals Ordinance as amended gave Aboriginal Australians some special rights and removed others, it did not remove the standing of Indigenous adults before the courts. ${ }^{61}$ Therefore, the Crown needed the permission of the Ross party in order to sue on their behalf.

This decision was not straightforward. Until 1953, section 7 of the Aboriginals Ordinance 1918-1947 (NT) had provided that:

1. The Director shall be the legal guardian of every aboriginal and of every half-caste child, notwithstanding that the child has a parent or other relative living, until the chil [sic] attains the age of eighteen years ... ${ }^{62}$

Kriewaldt held that, read in context, subsection 7(1) of the Aboriginals Ordinance only applied to children, Aboriginal and half-caste. ${ }^{63}$ He did so notwithstanding that obiter dicta from the High Court in Waters $v$ Commonwealth suggested that the provision actually made the Welfare Officer the legal guardian of 'all aboriginals' in the Territory. ${ }^{64}$

However, Kriewaldt then discovered that this version of section 7 was no longer in force, as it had been repealed by the Aboriginals Ordinance (No. 2) 1953 (NT), assented to on 25 June 1953. Section 7 therein had been simplified to read 'The Director is the legal guardian of all aboriginals' ${ }^{65}$ Kriewaldt read this section down on much less transparent grounds. He held, first, that the definition of 'aboriginal' was uncertain. He held, second, that the Ordinance, read as a whole, qualified or amplified the powers appertaining to the Director as 'legal guardian' so much that it rendered Aboriginal subjects nothing like 'wards' at common law. The Ordinance listed rather than assumed many powers that would automatically pertain to a 'legal guardian' at law. It purported to give the Director 'full care, custody and control' of Aboriginal adults only in enumerated circumstances. For example, it gave the Director explicit power to sue for wages, suggesting it gave no implicit power to sue for other ends. In other parts, the Ordinance imposed extraordinary limits on Aboriginal legal subjecthood: unlike wards, Aborigines were not emancipated on marriage nor on enlistment in the army. As the duties and powers of the Director could only

61 Transcript of Judgment, Ross $v$ Chambers, April 1956, NTWB 1955/1154, 101.

62 Transcript of Judgment, Ross $v$ Chambers, April 1956, NTWB 1955/1154, 100.

63 Transcript of Judgment, Ross $v$ Chambers, April 1956, NTWB 1955/1154, 99-100.

64 Transcript of Judgment, Ross $v$ Chambers, April 1956, NTWB 1955/1154, 197; (Waters v Commonwealth 82 CLR 188).

65 Section 7. An Ordinance to amend the Aboriginals Ordinance 1918-1947 (No. 9 of 1953), aiatsis.gov.au/ sites/default/files/docs/digitised_collections/remove/52398.pdf. 
be properly derived from the terms of the Ordinance and not from common law, adult Aborigines retained their right and obligation to sue on their own behalf. Reading down legislation restrictive of civil rights is a long-established maxim of statutory interpretation. But Kriewaldt's decision, by his own admission, went against both High Court dicta and decades of practice. Crown Law Officer R.J. Withnall observed that:

It is true that the interpretation of the section does present a good deal of difficulty but it seems to me that the interpretation which his Honour has given to it involves the reading into the section of qualifications and ideas that are nowhere expressed or even implied. I do not think that His Honour's decision is right. ${ }^{66}$

In this context, the Ross decision could be read as a product of policy as much as law - a robust endorsement of a basic tenet of legal assimilation. Kriewaldt contended, here and elsewhere, that Aboriginal inequality was transitory and did not alter their rights and obligations before courts of law. ${ }^{67}$ His insistence that Aborigines should stand as equals before the law was very different, and much more antiquated, than Hasluck's vision. Legal incorporation underpinned metropolitan efforts to protect slaves and Aborigines throughout the British Empire in the second quarter of the nineteenth century. ${ }^{68}$ Kriewaldt echoed sentiments expressed by Justice Burton of the Supreme Court of New South Wales in the infamous Murrell case of 1836 that extended British jurisdiction over crimes between Aborigines on the grounds that Aboriginal customary law could not survive the advent of British sovereignty in the colony of New South Wales. ${ }^{69}$ A few years after Ross, Kriewaldt would argue openly that law was a 'civilising medium' for Aboriginal people. ${ }^{70}$ Law would encourage Aboriginal people to forego extrajudicial punishments, like payback. Instead they would accept punishments and protections administered by the state. According to Kriewaldt, if Aboriginal people were to be assimilated 'in the sense that they shall become a permanent, integrated, and useful section of the community' they must be punished for crimes they committed, as well as obtain justice for those crimes perpetrated upon them. ${ }^{71}$ It was his opinion that 'all members of any given community are entitled to the benefits conferred by law, in return for which they become subject to the law and accept the restrictions laid down by the law'.$^{72}$ Those benefits, it is important to note, did not extend to full credibility in giving evidence, or to the right to be tried by a jury of peers. ${ }^{73}$

\footnotetext{
Withnall to Giese, 9 May 1956, NTWB 1955/1154, 117.

Douglas 2005.

Ford 2014.

Ford 2010: 196-203; Douglas and Finnane 2012: 37-41.

Douglas 2005: 35.

Douglas 2002, 2005: 15, 51; Kriewaldt 1960: 16.

Douglas 2005: 15.

Re native evidence: Transcript of Judgment, $R v$ Chambers, 47-50.
} 
Nor did they operate to hold Aborigines accountable for violent crime; in his decisions in criminal cases against Aborigines, Kriewaldt repeatedly mitigated Aboriginal sentences to compensate for their imperfect understanding of and integration into settler law. ${ }^{74}$

However qualified, Kriewaldt's was not the assimilation imagined by the Northern Territory Administration. Indeed, the administration's reaction to his decision is much more revealing of the logic of assimilation in the middle of the twentieth century. At one level, that logic reflected very real concerns about the disadvantages faced by Aborigines as legal subjects. As Giese pointed out to the Chief Administrator in early 1956, Indigenous people might be severely disadvantaged by their status as equal civil litigants before the courts. Some of these disadvantages were the result of government policy. Most insidiously, as systematically underpaid workers, and as wards whose access to wages was controlled by the state, Aboriginal litigants in the Territory had limited resources to bring suits. Giese worried that the Chambers brothers might challenge their suit 'on the grounds that the Aborigines have no means of paying the cost of such action' ${ }^{75}$

Second, Kriewaldt's finding put litigation in jeopardy because it required the administration to involve the victims much more intimately in the civil case. This was physically very difficult. Though Territory Aborigines numbered among the most administered and surveilled people in Australia, the Northern Territory was a big place. Aborigines involved in the pastoral industry worked on remote stations and their combination of wage labour with traditional practices like walkabout made them mobile. As a result, they were often temporarily outside the reach of the state. This mattered when, in theory, the Eva Downs victims had just 14 days after the delivery of Kriewaldt's judgment to decide whether they would like to pursue the litigation in their own names. The process of finding the Ross party after Kriewaldt's decision took nearly three months! The decision was handed down on 5 April 1956. The Crown Law Officer forwarded permission forms to regional welfare officers on 10 May. ${ }^{76}$ Evans sent a telegram to 'Manager Webb' at Borroloola on 23 May speculating that Dolly, Jim and Munro may have moved on to Seven Emus Station. ${ }^{77}$ Two days later they were believed to be en route to Borroloola. ${ }^{78}$ Constable Corbin was then enlisted in the effort to transport the party to the 'Brunette Occasion Race meeting to meet Patrol Officer Lovegrove' ${ }^{79}$ Lovegrove forwarded signed permissions from

74 Douglas and Finnane 2012: 121-47.

75 Giese to Archer, 6 April 1956, NTWB 1955/1154, 103.

76 Withnall to Giese, 10 May 1956, NTWB 1955/1154, 111.

77 Evans to Webb, 23 May 1956, NTWB 1955/1154, 114.

78 Webb to NT Administration, 25 May 1956, NTWB 1955/1154, 115.

79 Evans to Webb, 12 June 1956, NTWB 1955/1154, 120. 
all of the Eva Downs victims on 26 June. ${ }^{80}$ The Crown Law Officer, Withnall, did not hear of the permissions until 11 July. ${ }^{81}$ Demonstrating the continued importance of public opinion to the case, the minister asked that news of the permissions be sent on to the Council of Aboriginal Rights just one week later. ${ }^{82}$ The tight communication links between Hasluck and humanitarians contrast starkly with the enormous practical difficulties faced by Northern Territory administrators in bringing the Ross case back into court.

The other reaction of the administration to Kriewaldt's decision revealed the theoretical inconsistencies of assimilation policy. Administrators moved quickly to fill in the gaps in administrative control of adult Aborigines opened by Ross $v$ Chambers.$^{83}$ Giese and the Crown Law Officer recommended immediate appeal to the High Court against Kriewaldt's decision. Withnall noted the danger the decision posed, not only to the welfare infrastructure established by the expiring Aboriginal Ordinance, but also to the new system established by the 1953 Welfare Ordinance. ${ }^{84}$ Crown Solicitor, H.E. Renfree, disagreed. In May, he warned that an appeal might not be successful. Indeed, he agreed with Kriewaldt's finding:

whatever it does mean it [the phrase 'legal guardian'] cannot take away the legal right of aboriginals of full age and sane minds to conduct their own litigation. If that is not the Government's intention, I think the proper course is to amend the legislation to make it clear.${ }^{85}$

Amendment became the first priority of the Department of Territories within a fortnight. ${ }^{86}$ Secretary Lambert asked the Welfare Office in Darwin to help. As Assistant Administrator Lawrie put it in late August:

The Director should be able to exercise all the rights and duties that are normally entrusted to a guardian in relation to an infant ward and if the Welfare Ordinance, as it now stands, does not permit him to do so it should be amended appropriately. ${ }^{87}$

Lawrie noted that the new Ordinance already gave the Welfare Administrator most of the powers of guardianship at law, and recommended that it be explicitly expanded to include the power to bring suits as a 'next friend' ${ }^{88}$ But this raised a number of problems. At law, a guardian or next friend was personally liable

\footnotetext{
80 Lovegrove to Giese, 26 June 1956, NTWB 1955/1154, 131.

81 Giese to Withnall, 11 July 1956, NTWB 1955/1154, 133.

82 Minister's Office to 'Admin Darwin', 18 July 1956, NTWB 1955/1154, 134.

83 Lawrie to Withnall, 22 August 1956, NTWB 1955/1154, 138.

84 Withnall to Renfree, 9 May 1956, NTWB 1955/1154, 117.

85 Renfree to Lambert, 25 May 1956, NTWB 1955/1154, 122.

86 Lambert to Archer, 13 June 1956, NTWB 1955/1154, 124.

87 Lawrie to Withnall, 2 August 1956, NTWB 1955/1154, 138.

88 Lawrie to Withnall, 2 August 1956, NTWB 1955/1154, 136.
} 
for the costs of litigation. It also raised a problem when wards sued each other as the 'Director could not be next friend to both' ${ }^{89}$ Withnall had addressed these problems in a new draft amendment by 3 September. ${ }^{90}$ This amendment, designed to undo the radical ramifications of the Chambers case, operated to constrain Aboriginal subjecthood from 1957 to 1964. It gave the Director of Welfare unambiguous power to bring suits on behalf of Aboriginal 'wards'.

All that remained, then, was to conclude the civil suit against the Chambers brothers to the satisfaction of the administration's humanitarian critics. This process exposed important tensions within the administration about the character of Aboriginal subjecthood and the responsibilities of the state for their welfare. In September, Newell and Ward, solicitors for the Chambers brothers, offered very modest financial settlements to the victims - a total of £220, onetenth of the damages claimed in the initial civil suit. Under this settlement, Jim Ross was offered £100, Dolly, £50, Isaacs, £50, Munro, £10 and McDinny, £10. Withnall refused to recommend this settlement to the Ross family. However, he recommended to Giese that the clients accept a more generous settlement of $£ 520$ (just over one-quarter of the original claim): $£ 400$ of this would go to the Ross family, $£ 70$ to Isaac Isaacs, and $£ 25$ each to Munro and McDinny. ${ }^{91}$

Archer resisted, a strained mixture of condescension and wariness of public opinion underpinning his response. The Chief Administrator for the Territory pointed out:

Right throughout the whole of the proceedings relating to this assault case, our actions and advice have been guided by our acceptance of a responsibility to see that substantial justice was not only done; but that it also much appear to be done. ${ }^{92}$

It was not clear that this settlement would achieve either. He complained that the amount of damages initially claimed and the settlement proposed by Withnall 'differs so widely that I most certainly do not feel competent to sit in judgment on the matter'. If the Crown Solicitor could demonstrate that the initial claim was 'excessively high' then he might be 'prepared to consider advising a settlement in the public interest'. But as 'the Crown Law Officer does not feel able to do that', Archer felt that his duty under the Ordinance required him to allow 'the matter to proceed to judgment in the court' ${ }^{93}$

\footnotetext{
89 Withnall to Lawrie, 4 August 1956, NTWB 1955/1154, 137.

90 Withnall to Giese, 3 September 1956, NTWB 1955/1154, 140-41. Only subsection (3) giving the Director power to determine in which religious faith a ward 'should be brought up' was occluded. This last power, Chief Administrator Archer argued, was neither 'necessary nor desirable': Archer to Lambert, 10 September 1956, NTWB 1955/1154, 143. Approved by minister, Lambert to Giese, 19 September 1956, NTWB 1955/1154, 146.

91 Withnall to Giese, 7 September 1956, NTWB 1955/1154, 145.

92 Archer to Giese, 22 October 1956, NTWB 1955/1154, 151.

93 Archer to Giese, 22 October 1956, NTWB 1955/1154, 151.
} 
Archer's discomfort was reflected in Withnall's more fulsome reply. Withnall confined his examination to the case of Munro who, as a minor, could be represented without his consent by the Director of Welfare despite Kriewaldt's decision in Ross. Withnall explained that the difficulty with the case lay in determining the nature of damage sufferable by an Aboriginal worker like Munro. Ordinary cases of assault determined special damages on the basis of expenses. But ascertaining the wages lost by an Aboriginal child worker was not easy, and, though none of the party was employed between September 1956 and January 1957, only one week's lost wages could fairly be attributed to their wounds. Munro could expect no more than $£ 3$ for a week's work if he was paid as an adult. Dolly and other Aboriginal women could only expect 10/- to $£ 1$ per week. ${ }^{94}$ General damages assessed non-pecuniary losses - for example, the 'pain and suffering endured' by the victims. These might range from nothing (for the 'transitory' pain of a 'slap in the face') to $£ 5,000$ for serious injury. The perpetrators alleged that Munro was scarcely beaten, and the Crown Solicitor thought that $£ 25$ would suffice to cover his pain and suffering. 'Exemplary' or 'punitive' damages might further compensate Munro for the outrage and 'indignity' of being beaten. This head of damage rested on evidence of the victim's wounded pride. However, 'the circumstances of the assault, namely a deserted road far from the presence of others, and the social standing of the plaintiffs as labourers on a pastoral station, does nothing to increase the prospect of any large award under this head'. Withnall was careful to note that the "mere fact that the plaintiff is an aboriginal is not relevant to reduce the amount of damages'. But he did concede that 'the facts of his occupation and standing in the community are to be taken into account' ${ }^{95}$ Munro's 'standing in the community' could hardly be read without reference to his Aboriginality defined as race or culture. Under the old and new welfare legislation, Munro could not command equal wages, could not control his own money and could be told where to live and with whom he could associate. Archer clearly sensed the danger here. He argued, again, that 'because of the principles involved the matter should take its course and be settled in and by the Court' ${ }^{96}$

Regardless of the administration's decision in the case of Munro, the Crown Law Officer noted that Giese was obliged to offer the terms of settlement to the adult victims. He advised moreover, that, under the Ross decision, Jim and Dolly Ross, Isaac Isaacs and Dinny McDinny would 'have to decide for themselves' whether to 'accept an out of court settlement' without 'persuasion of any kind by an officer of the Welfare Branch'.${ }^{97}$ Archer was troubled by the ramifications of this advice: 'surely we still have some general responsibility and some form

94 Referring to memorandum, Giese to Withnall, 5 March 1956, NTWB 1955/1154, 80.

95 Withnall to Giese, 25 October 1956, NTWB 1955/1154, 152-54.

96 Annotation by Archer, 30 October 1956, on Withnall to Giese, 25 October 1956, NTWB 1955/1154, 152.

97 Archer to Lambert, undated draft (February 1957), NTWB 1955/1154, not paginated. 
of status in an advisory capacity where an important matter affecting welfare is involved'.$^{98}$ Local officers worried that the victims would not understand the terms of settlement. When the trusty Constable Corbin related the settlement offer to Dinny McDinny on 7 January, he felt that McDinny had not 'fully understood what I was trying to explain to him'. ${ }^{99}$ When he finally tracked down most of the party at Borroloola in mid-March, Patrol Officer E.O. Harvey clearly felt it important to make some odd concessions to language difficulties. Each of the thumb-printed consent forms read 'Mr. Harvey bin explain to me that Chambers wants to pay me $£[X]$ to finish that whipping business at Eva Downs Station. I understand properly and will take the $£[X]^{\prime} .{ }^{100}$

Importantly, when they signed these release forms the Ross family, McDinny and Isaacs declared that 'they would not want anything more to do with the case' $^{\prime}$ of Munro. ${ }^{101}$ It was now early 1957, more than a year after the criminal trial, and the adult victims were all eager to move on. Withnall agreed with them. He worried that the passage of time alone would make the victims bad witnesses in Munro's civil suit, and if they refused to give evidence, he thought the case could scarcely succeed in their absence. ${ }^{102}$ Archer conceded that their reluctance might make it 'impossible for us to proceed with the case on behalf of Munro':

I am concerned that we have been forced into this position by Mr. Justice Kriewaldt's judgment and by the subsequent action of the four natives in accepting out of Court settlements, and I can appreciate that if and when it is known that a settlement out of Court has been agreed to by the natives, the Administration could come in for some criticism. However, I think we might find the position to be more damaging if we were to continue proceedings on behalf of Munro and then find in the absence of any evidence from the other natives that the decision went against us. ${ }^{103}$

Archer wavered, however, when the post-Ross $v$ Chambers amendment of the Welfare Ordinance came into effect. Section 24 gave him explicit power to act on behalf of all Aborigines declared to be wards under the 1953 Ordinance. This provision included all of the victims of the Eva Downs incident. He considered, again, whether he should force Ross and his kin into court both as litigants and witnesses. Withnall's response makes the tension between civil rights and protection very clear. He protested against the impropriety of dishonouring the agreements signed by the Rosses, McDinny and Isaacs in

\footnotetext{
98 Annotation by Archer, 15 January 1957 on Lambert to Archer, 9 January 1957, NTWB 1955/1154, 163; reiterated Archer to Lambert, 22 February 1957, NTWB 1955/1154, 166 (requesting advice from the minister). 99 Corbin to Giese, 7 January 1957, NTWB 1955/1154, 163.

100 E.g. Statement of Aboriginal Dinny, 18 March 1957, NTWB 1955/1154, 175 (compare 172-74).

101 Giese to Withnall, 10 April 1957, NTWB 1955/1154, 179.

102 Withnall to Giese, 11 April 1957, NTWB 1955/1154, 181.

103 Archer to Lambert, 15 April 1957, NTWB 1955/1154, 182.
} 
that brief period in which they were considered to be legal adults. He pointed out that the duty of the Commonwealth lay, not in the defence of its policy, but in defence of the 'particular welfare of the four persons in question'. Most importantly, he explained that pursuing the policy of the Commonwealth would require the forced relocation and testimony of the victims - a violation of their wishes and their interests.

[I]n light of the statements of the aboriginals as to their unwillingness to proceed you will, I am sure, realise that it is in the interests of the aboriginal plaintiffs to accept the offer which has been made and quite contrary to their interests to reject it. If the proceedings go on and it becomes obvious, as I feel sure that it must become obvious, that the aboriginals have been brought to Darwin against their wish, then I think quite proper and damaging criticism both from the Court and from the public may be directed at the Director of Welfare. ${ }^{104}$

Archer bristled at this imputation. In a letter to the Secretary of the Territory in Canberra, he defended the conflation of policy and the victims' welfare, arguing that Withnall had taken too narrow a view of 'government policy'. The Welfare Officer, he noted, is something like a 'member of the Legislative Council': he is a representative of individuals and 'an appointee of the Crown'. His decisions, therefore, affected 'all concerned (including the aborigines)' involved in the case. In Archer's view, in this case, the general and particular interest required the cases to go to court. ${ }^{105}$

Hasluck, however, sided with Withnall. ${ }^{106}$ On 22 October, Lambert communicated Hasluck's approval of the negotiated settlements and he authorised Withnall to agree to settle Munro's claim out of court. ${ }^{107}$ This payment, minus $£ 42-2$ costs deducted by the Crown Solicitor, was not placed at the victims' disposal until sometime between May and October 1958, more than two-and-a-half years after their beating near Eva Downs - a telling performance of the hubris underpinning the Northern Territory Administration's efforts at intimate Indigenous governance. ${ }^{108}$

104 Withnall to Archer, 30 July 1957, NTWB 1955/1154, 197-99.

105 Archer, unsigned draft to Lambert, 31 July 1957, 200; Archer to Lambert, 7 August 1957, 202-3; Hamilton to Giese, 7 October 1958, 230 ('wards' contacted 'some time ago ... and notified of their improved financial positions'), Hamilton to Giese, 24 October 1958, 231. All in NTWB 1955/1154.

106 JS to Giese, 28 August, NTWB 1955/1154, 207; Lambert to Archer, 30 August 1957, NTWB 1955/1154, 211. 107 Giese to Withnall, 30 August 1957, NTWB 1955/1154, 208.

108 Bill of Costs, undated, NTWB 1955/1154, 219-22; Approval of costs, Ryan to Archer, 20 January 1958, NTWB 1955/1154, 223. 


\section{Conclusion}

This intricate story of shifting positions, practical difficulties, interdepartmental quarrels and public pressure demonstrates several important aspects of assimilation in practice in the 1950s. The case itself demonstrates the Northern Territory Administration's efforts to lead the states by example by holding employers accountable for the abuse of Aboriginal workers. It was also crafted in response to east coast humanitarian criticism: a sign of the sensitivity of government to United Nations scrutiny; and of its sense that Aboriginal rights were fast becoming an electoral issue in Australia. At the same time, by insisting on Aboriginal equality before the law, Kriewaldt's decision in the Ross case itself highlights the distance between assimilation policy and legal ideology at mid-century. Far from seeing the courts as a medium of Aboriginal civilisation, administrators saw them alternatively as a threat to Aboriginal subjects and as sites for the public performance of Aboriginal protection. Their desire to ward off criticism and to lead the nation was fatally hampered by Kriewaldt's formulation of Aboriginal legal subjecthood. If Aboriginal agency played a role in the incident at Eva Downs, then Aboriginal agency posed a deeper threat to the capacity of the administration to set a national standard for the protection of Aboriginal workers in the 1950s. In this logic, it is little wonder that the administration sought to close down Aboriginal agency by insisting that its Aboriginal wards were in the thrall of the state. The Eva Downs incident puts the ideological paradox of mid-century Aboriginal protection on full display.

\section{References}

Attwood, Bain 2003, Rights for Aborigines, Allen \& Unwin, Crows Nest, NSW.

Berndt, Ronald M. and Catherine H. Berndt 1987, End of an Era: Aboriginal Labour in the Northern Territory, Australian Institute of Aboriginal Studies, Canberra.

Broome, Richard 2010, Aboriginal Australians: A History since 1788, 4th edn, Allen \& Unwin, Crows Nest, NSW.

Bunbury, Bill 2002, It's Not the Money It's the Land: Aboriginal Stockmen and the Equal Wages Case, Fremantle Arts Centre Press, North Fremantle, WA.

Chesterman, John and Heather Douglas 2009, 'Law on Australia's northern frontier: The fall and rise of race', Canadian Journal of Law and Society 24: 69-83. 
Douglas, Heather 2002, 'Justice Kriewaldt, Aboriginal identity and the criminal law', Criminal Law Journal 26: 204-21.

2004, 'Assimilation, Lutheranism and the 1950s justice of Kriewaldt', Australian Journal of Legal History 8: 285-312.

2005, 'Legal Narratives of Indigenous Existence: Crime, Law, and History', PhD thesis, University of Melbourne.

Douglas, Heather and Mark Finnane 2012, Indigenous Crime and Settler Law: White Sovereignty after Empire, Palgrave, Basingstoke.

Ford, Lisa 2010, Settler Sovereignty: Jurisdiction and Indigenous People in America and Australia, 1788-1836, Harvard University Press, Cambridge, MA.

2014, 'Anti-slavery and the reconstitution of empire', Australian Historical Studies 45(1): 71-86.

Galligan, Brian and John Chesterman 1997, Citizens without Rights: Aborigines and Australian Citizenship, Cambridge University Press, Cambridge.

Haebich, Anna 2000, Broken Circles: Fragmenting Indigenous Families, 1800-2000, Fremantle Arts Centre Press, Fremantle.

Hall, Robert A. 1989, The Black Diggers: Aborigines and Torres Strait Islanders in the Second World War, Allen \& Unwin, St Leonards, NSW.

Hasluck, Paul 1988, Shades of Darkness: Aboriginal Affairs 1925-1965, Melbourne University Press, Carlton, Vic.

Hokari, Minoru 2011, Gurindji Journey, University of New South Wales Press, Crows Nest, NSW.

Holland, Alison 2001, 'Wives and mothers like ourselves: Exploring white women's intervention in the politics of race, 1920s-1940s', Australian Historical Studies 32(117): 292-310.

2015, Just Relations: The Story of Mary Bennett's Crusade for Aboriginal Rights, UWA Publishing, Crawley.

Kerin, Rani 2011, Doctor Do-Good: Charles Duguid and Aboriginal Advancement, 1930s-1970s, Australian Scholarly Publishing, North Melbourne.

Kriewaldt, Martin 1960, 'The Application of the Criminal Law to the Aborigines of the Northern Territory of Australia', 15th Annual Conference of the Australian Universities Law Schools Association. 
Kruger, Alec Bumbolili 2007, Alone on the Soaks: The Life and Times of Alec Kruger, IAD Press, Alice Springs.

May, Dawn 1983, From Bush to Station, James Cook University of North Queensland, Townsville.

1994, Aboriginal Labour and the Cattle Industry: Queensland from White Settlement to the Present, Cambridge University Press, Cambridge.

McDinny, Eileen 1987, Unpublished Interview by John Bradley [Tape Recording], September, 1987. Translated from Yanyuwa in September 2006.

McEwen, J. 1939, 'The Northern Territory of Australia: Commonwealth Government's policy with respect to Aboriginals', National Library of Australia, www.nla.gov.au/apps/doview/nla.aus-vn4690481-p.pdf.

McGrath, Ann 1987, Born in the Cattle: Aborigines in Cattle Country, Allen \& Unwin, Sydney.

McGregor, Russell 1999, 'Wards, words and citizens', Oceania 69: 243-59.

2005, Avoiding "Aborigines": Paul Hasluck and the Northern Territory Welfare Ordinance, 1953', Australian Journal of Politics and History 51: 513-29.

2011, Indifferent Inclusion: Aboriginal People and the Australian Nation, Aboriginal Studies Press, Canberra.

Murphy, John 2013, 'Conditional inclusion: Aborigines and welfare rights in Australia, 1900-47', Australian Historical Studies 44(2): 206-26.

Nettelbeck, Amanda 2012, "A halo of protection": Colonial Protectors and the policy of Aboriginal protection as punishment', Australian Historical Studies 43(3): 396-411.

Nettelbeck, Amanda and Robert Foster 2007, In the Name of the Law: William Willshire and the Policing of the Australian Frontier, Wakefield Press, Kent Town, SA.

Northern Territory Welfare Branch - Eva Downs Station 1955-1958, National Archives of Australia, series F1, item 1955/1154.

O'Brien, Anne 2015, Philanthropy and Settler Colonialism, Palgrave Macmillan, Houndmills.

Powell, Alan 1982, Far Country: A Short History of the Northern Territory, Melbourne University Press, Melbourne. 
Riseman, Noah 2012, Defending Whose Country? Indigenous Soldiers in the Pacific War, University of Nebraska Press, Lincoln.

Roberts, Tony 2009, 'The Brutal truth: What happened in the Gulf Country', The Monthly 51, www.themonthly.com.au/issue/2009/november/1330478364/ tony-roberts/brutal-truth.

Rowley, C.D. 1970, The Destruction of Aboriginal Society, Australian National University Press, Canberra.

Rowse, Tim 1998, White Flour, White Power: From Rations to Citizenship in Central Australia, Cambridge University Press, Cambridge.

- 2012, Rethinking Social Justice: From 'Peoples' to 'Populations', Aboriginal Studies Press, Canberra.

Saunders, Kay 1995, 'Inequalities of sacrifice: Aboriginal and Torres Strait Islander labour in northern Australia during the Second World War', in Aboriginal Workers, Ann McGrath, Kay Saunders and Jackie Huggins (eds), Australian Society for the Study of Labour History, Sydney.

Sing, Peter 1992, From Humpy to Homestead: The Biography of Sabu, Pearl Ogden, Darwin. 
This text is taken from Aboriginal History, Volume 40, 2016, edited by Liz Conor, published 2016 by ANU Press,

The Australian National University, Canberra, Australia. 